\title{
French normative data and naming times for action pictures
}

\author{
VALÉRIE SCHWITTER \\ Geneva University Hospitals, Geneva, Switzerland \\ BRUNO BOYER, ALAIN MÉOT, and PATRICK BONIN \\ Blaise Pascal University, Clermont-Ferrand, France \\ and \\ MARINA LAGANARO \\ Geneva University Hospitals, Geneva, Switzerland
}

\begin{abstract}
The aim of the present study was to provide French normative data for 112 action line drawings. The set of action pictures consisted of 71 drawings taken from Masterson and Druks (1998) and 41 additional drawings. It was standardized on six psycholinguistic variables - that is, name agreement, image agreement, image variability, visual complexity, conceptual familiarity, and age of acquisition (AoA). Naming latencies to the action pictures were collected, and a regression analysis was performed on the naming latencies, with the standardized variables, as well as with word frequency and length, taken as predictors. A reliable influence of AoA, name agreement, and image agreement on the naming latencies was observed. The findings are consistent with previous published studies in other languages. The full set of these norms may be downloaded from www.psychonomic.org/archive/.
\end{abstract}

Many normative studies have already been carried out on the naming of object pictures in several languages (Alario \& Ferrand, 1999; Bonin, Peereman, Malardier, Méot, \& Chalard, 2003; Cuetos, Ellis, \& Alvarez, 1999; Dell'Acqua, Lotto, \& Job, 2000; Snodgrass \& Vanderwart, 1980), providing data that can be used in psycholinguistic research, as well as for clinical purposes. In contrast with noun studies, the interest in action pictures and verb production normative studies is quite recent. Until the early 1980 s, the interest in verbs came mainly from neurolinguistic studies, which focused on the use of verbs within sentences and on its deficit in Broca's aphasia. Nowadays, the interest in verbs is more diversified, and researchers have dissociated themselves from the exclusive link between agrammatism and deficits of verbs (Bastiaanse, Hugen, Kos, \& van Zonneveld, 2002). However, there are several differences between nouns and verbs. Double dissociations between production of nouns and verbs have been reported in aphasic speakers (e.g., Caramazza \& Hillis, 1991; McCarthy \& Warrington, 1985; Rapp \& Caramazza, 1998). Neuroimaging and electrophysiological data suggest that nouns and verbs activate different parts of the brain (e.g., Damasio \&

This research was partly supported by Grant 105312-100741 from the FNRS. The authors thank Roberto Dell'Acqua, Jonathan Vaughan, and one anonymous reviewer for their helpful comments on an earlier version of this article. Correspondence should be addressed to V. Schwitter, Hôpitaux Universitaires de Genève, Service de Rééducation, Av. de BeauSéjour 26, CH-1211 Geneva 14, Switzerland (e-mail: valerie.schwitter@ hcuge.ch).
Tranel, 1993; Molfese, Burger-Judisch, Gill, Golinkoff, \& Hirsch-Pasek, 1996). This evolution has opened perspectives for new research and has encouraged the recording of normative data for verbs (Druks, 2002). In the normative studies of action pictures, the same variables that had already been analyzed in the normative studies of object pictures have been considered. Among these variables, we can distinguish visual and semantic factors (visual complexity [VC], image agreement [IA], image variability [IV], and conceptual familiarity [Fam]), lexical factors (name agreement [NA], age of acquisition [AoA], and word frequency) and phonological factors (word length; for a review, see Alario et al., 2004).

Certain normative studies of action pictures, most of them conducted in English, may thus be cited as important contributions to this domain. Fiez and Tranel (1997) were among the first to develop standardized material for the naming of action pictures. Their material consisted of 280 action photographs, which were standardized on four psycholinguistic variables (IA, Fam, NA, and VC). The work by Masterson and Druks (1998) represents an important step in providing a set of standardized line drawings of actions. Relying on an observation by Berndt, Mitchum, Haendiges, and Sandson (1997) showing that there are no significant differences in aphasic speakers in naming accuracy for video sequences and pictures, the authors developed a battery consisting of 102 black-andwhite action line drawings and standardized their material with a 7-point rating task on four variables - namely, AoA, Fam, imageability, and VC. Cuetos and Alija (2003) used this same material as a basis for a normative 
study in Spanish. Besides standardizing the Masterson and Druks material on the same factors and with the same rating method with Spanish speakers, the authors also collected naming times on the same pictures. The study showed that AoA and NA were reliable predictors of naming times for action pictures.

A study by Bonin, Boyer, Méot, Fayol, and Droit (2004) was the first normative work developed for verbs in French. In this study, rated norms were collected on action photographs taken from Fiez and Tranel (1997), and picture naming times were collected. NA, IA, and AoA significantly affected both written and spoken naming latencies, and word length affected written naming latencies.

Since line drawings are used mostly in psycholinguistic, as well as in clinical, naming tasks, the goal of the present study was to standardize action pictures and verbs for picture production for French. By analogy to previous studies, we first collected rated norms for the classical psycholinguistic variables on pictures and on the corresponding verbs. Then, pictures naming times were collected, and a regression approach was used to determine the reliable predictors of naming speed for action pictures.

\section{NORMATIVE STUDY}

This study provides French normative data for the Masterson and Druks (1998) pictures and for 41 other line drawings. The action pictures and the corresponding modal verbs were standardized on six variables - that is, NA, IA, IV, VC, Fam, and AoA.

\section{Method}

Participants. A total of 188 psychology students at the University of Geneva took part in this study. The participants (136 women and 44 men; mean age, 25 years) were all French native speakers and participated voluntarily. The participants were randomly assigned to the different rating tasks. Thirty-eight participants were involved in the preliminary task leading to NA, and 30 participants were involved in each of the five other rating tasks.

Materials. The initial material consisted of 172 line action pictures: 100 pictures were taken from the Masterson and Druks (1998) database, and the remaining 72 line drawings were specifically produced by an artist. Among these stimuli, only those with an NA superior to or equal to $80 \%$ of the participants' producing the modal verb were accepted for the following rating tasks. Thus, the final set retained for inclusion in the normative study consisted of 112 pictures. In order to indicate the distinction between the sets of pictures, the line drawings taken from the Masterson and Druks database are designated by $M D$, and the ones added by $V S$ (see Appendixes $\mathrm{A}$ and $\mathrm{B}$ ).

Procedure. The procedure closely followed the one adopted by Masterson and Druks (1998) and by Cuetos and Alija (2003) in their study on action pictures. Fam, IA, VC, IV, and AoA were evaluated through a subjective judgment. However, contrary to the Masterson and Druks study, which used a 7-point scale in the IA, Fam, VC, IV, and AoA judgment tasks, we used a 5-point scale (the same rating scale used in other French studies by Alario \& Ferrand, 1999, and Bonin et al., 2003).

At the beginning of each task, the aim and the order of the experiment were clearly explained to the participants. They were par- ticularly informed about the pictures' nature - that is, relatively simple line drawings.

In the NA task, the 172 pictures were projected sequentially on a white screen before a slightly darkened audience. Each picture was presented for $6 \mathrm{sec}$. An individual five-page booklet was distributed to the participants, in order to note down their answers. They had to identify each picture with the first verb that came to mind and to note it down during the $6 \mathrm{sec}$ of projection.

In the IA task, the pictures were projected sequentially on a computer screen to the participants by groups of three to eight. Individual sheets of paper were distributed with which to note down their answers. This experiment was carried out in three steps. For each action, the written verb was projected for $2 \mathrm{sec}$, followed by a white screen lasting $3 \mathrm{sec}$. The participants were asked to mentally represent the action corresponding to the verb. The corresponding picture was finally presented for $5 \mathrm{sec}$, and the participants had to indicate on a 5-point scale the degree of accordance between their mental picture and the projected picture (with $1=$ low degree of correspondence and $5=$ very high degree).

For the Fam and the VC tasks, the pictures were presented on individual sheets of paper (four pictures on each). For the Fam rating task, the participants had to indicate on a 5-point scale their familiarity with the action depicted by the picture. Fam was defined as "the degree to which the participant comes in contact with the action or thinks about the action" $(1=$ very unfamiliar and $5=$ very familiar). There was no time constraint on performance of this task.

For the VC task, the participants had to rate on a 5-point scale the $\mathrm{VC}$ of the picture. VC was defined as "the amount of lines and details in the drawing" ( $1=$ very simple drawing and $5=$ very complex drawing). There was no time constraint on performance of the task.

In both the IV and the AoA rating tasks, a written list of verbs was provided. For the IV task, the participants had to indicate on a 5 -point scale whether the verb evoked few or many different mental images $(1=$ few different images and $5=$ many different images), whereas in the AoA rating task, they had to estimate the age at which they thought they had learned each verb $(1=$ learned before 3 years old and $5=$ learned after 12 years, each point on the scale representing 3 years).

\section{Results}

A total of 112 drawings ( 71 from the MD set and 41 from the VS set) were provided, each with a single verb whose NA was higher than or equal to $80 \%$. Table 1 shows the means and standard deviations for each rated variable.

For the correlational analysis, word frequency and length (number of syllables and phonemes) of the modal names were also considered. The word frequency values per million were obtained from the French database LEXIQUE (New, Pallier, Ferrand, \& Matos, 2001) and

Table 1

Means and Standard Deviations for the Five Rated Variables

\begin{tabular}{|c|c|c|c|c|c|c|}
\hline \multirow[b]{2}{*}{ Variable } & \multicolumn{2}{|c|}{ MD Pictures } & \multicolumn{2}{|c|}{ VS Pictures } & \multicolumn{2}{|c|}{ Total Pictures } \\
\hline & $M$ & $S D$ & $M$ & $S D$ & $M$ & $S D$ \\
\hline Image agreement & 3.82 & 0.21 & 3.7 & 0.29 & 3.8 & 0.21 \\
\hline Familiarity & 3.12 & 0.92 & 2.82 & 0.84 & 3.02 & 0.9 \\
\hline Visual complexity & 2.95 & 0.70 & 2.77 & 0.47 & 2.89 & 0.68 \\
\hline Image variability & 2.54 & 0.62 & 2.35 & 0.54 & 2.47 & 0.6 \\
\hline Age of acquisition & 2.23 & 0.62 & 2.46 & 0.57 & 2.31 & 0.61 \\
\hline
\end{tabular}

Note-MD, pictures from Masterson and Druks, 1998; VS, added pictures. 
Table 2

Correlation Matrix Among All Variables

\begin{tabular}{|c|c|c|c|c|c|c|c|c|c|}
\hline & NA & IA & Fam & $\mathrm{VC}$ & IV & AoA & F-Lex & NbSyll & NbPho \\
\hline NA & 1.00 & & & & & & & & \\
\hline IA & .252 & 1.00 & & & & & & & \\
\hline Fam & .199 & .176 & 1.00 & & & & & & \\
\hline $\mathrm{VC}$ & -.085 & .010 & -.159 & 1.00 & & & & & \\
\hline IV & .164 & -.249 & $.464^{*}$ & -.133 & 1.00 & & & & \\
\hline AoA & -.181 & .275 & $-.453 *$ & .330 & $-.649 *$ & 1.00 & & & \\
\hline F-Lex & .066 & -.311 & $.386^{*}$ & -.164 & $.657 *$ & $-.551^{*}$ & 1.00 & & \\
\hline NbSyll & -.093 & -.055 & . 106 & .144 & -.107 & .093 & -.135 & 1.00 & \\
\hline NbPho & -.015 & .103 & .227 & .076 & -.101 & .065 & -.133 & $.785^{*}$ & 1.00 \\
\hline
\end{tabular}

Note-NA, name agreement; IA, image agreement; Fam, familiarity; VC, visual complexity; IV, image variability; AoA, age of acquisition; F-Lex, lexical frequency; NbSyll, number of syllables; NbPho, number of phonemes. *Relevant correlations $(p<.0001)$.

were log-transformed. The correlations between variables are shown in Table 2. The significant correlations between AoA and Fam, AoA and IV, and between AoA and word frequency were negative, and positive correlations can be observed between IV and Fam, word frequency and Fam, word frequency and IV, and numbers of syllables and phonemes.

In order to compare our results with those of previous studies, we calculated pairwise correlations between our results and those of Masterson and Druks (1998) in English and Cuetos and Alija (2003) in Spanish for the common Masterson and Druks items. The correlations do not include IA, since this variable was not considered in these two studies and the results for the NA variable is not available in the English study. Significant interstudy correlations appear for the following variables: Fam, $\mathrm{VC}, \mathrm{AoA}$, and word frequency. These correlations are higher between English and French than between Spanish and French. The strongest correlations are observed for $\mathrm{VC}$ and AoA. There are no significant interlanguage correlations for IV, number of syllables, and number of phonemes (see Table 3).

\section{NAMING TIME}

\section{Method}

Participants. A total of 40 students, 25 from the University Blaise Pascal of Clermont-Ferrand and 15 from the University of

Table 3

Correlations With the Results of Previous Studies

\begin{tabular}{lcc}
\hline \multirow{2}{*}{ Variable } & \multicolumn{2}{c}{ Correlation } \\
\cline { 2 - 3 } Name agreement & French/English ${ }^{\mathrm{a}}$ & French/Spanish \\
\hline Image agreement & not studied & .186 \\
Familiarity & $.717^{\mathrm{b}}$ & not studied \\
Visual complexity & $.875^{*}$ & $.559^{*}$ \\
Image variability & .259 & $.830^{*}$ \\
Age of acquisition & $.858^{*}$ & .170 \\
Lexical frequency & $.658^{*}$ & $.732^{*}$ \\
Number of syllables & .076 & $.510^{*}$ \\
Number of phonemes & -.072 & .390 \\
* Relevant correlations $(p<.0001) . \quad{ }^{\text {aMasterson }}$ and Druks, 1998. \\
bCuetos and Alija, 2003.
\end{tabular}

Geneva took part in this experiment. All were French native speakers. None of them had participated in the normative study.

Materials. The action line drawings were the same as those in the normative study.

Procedure. The participants were tested individually in a small room. They were seated in front of the screen and carried a headmounted microphone. The participants were asked to name, as quickly as possible, a picture that appeared on the screen with a verb in the infinitive form. The pictures were presented randomly across participants. A short break was given to the participants after every 35 items. The experiment was run with DMDX software (Forster \& Forster, 2003) on a PC computer. The participants' responses naming latencies and spoken responses were recorded.

Each picture was presented in the center of the screen. An experimental trial had the following structure: A "+" sign appeared in the middle of the screen for $500 \mathrm{msec}$, followed by the picture, which remained on screen until the voice key was triggered.

\section{Results}

Responses were considered incorrect and were excluded whenever a verb did not correspond to the modal verb, when no naming response was provided, or when a technical problem occurred. The rate of incorrect responses reached $16 \%$. We also excluded from the analysis five verbs that led to fewer than $50 \%$ correct responses (compter [to count; 48\%], sculpter [to sculpt; 45\%], jurer [to swear; 43\%], dépasser [to pass; 40\%], and s'appuyer [to lean; $38 \%]$ ). Thus, the following analyses were carried out on 107 items. With regard to the naming reaction times, no latencies were above $500 \mathrm{msec}$ once we excluded technical problems and responses starting with a nonlinguistic noise; at the other extreme, we removed naming latencies higher than $3,000 \mathrm{msec}$.

The average naming time was $1,097 \mathrm{msec}$, with a standard deviation of $195 \mathrm{msec}$. The MD images were generally named more quickly than the other drawings, with a mean naming time of $1,050 \mathrm{msec}(S D=183 \mathrm{msec})$. The mean naming time for VS images was $1,187 \mathrm{msec}$ $(S D=187 \mathrm{msec})$.

Correlations were calculated between the naming times and the nine variables mentioned in the normative study (see Table 4). Only VC and length in phonemes did not show significant correlations with naming times.

We conducted a multiple regression analysis with naming latency as the dependent variable and the seven pre- 
Table 4

Correlations Between Reaction Time (RT) and the Independent Variables

\begin{tabular}{cccccccccc}
\hline & NA & IA & Fam & VC & IV & AoA & F-Lex & NbSyll & NbPho \\
\hline RT & $-.430^{* *}$ & $-.424 * *$ & $-.301 *$ & .173 & $-.227^{*}$ & $.225^{*}$ & $-.195^{*}$ & $.223^{*}$ & .130 \\
\hline
\end{tabular}

Note-NA, name agreement; IA, image agreement; Fam, familiarity; VC, visual complexity; IV, image variability; AoA, age of acquisition; F-Lex, lexical frequency; NbSyll, number of syllables; NbPho, number of phonemes; RT, reaction time. * Relevant correlations $(p<.05) . \quad * *$ Relevant correlations $(p<.01)$.

dictors that correlated significantly with naming times. Naming time scores were log-transformed. The regression equation was significant $[F(7,289)=12.053, p<$ $\left..0001 ; r^{2}=.460\right]$. NA, IA, and AoA were reliable predictors of naming latencies (see Table 5).

We compared our results with those of a previous French study on photographs (Bonin et al., 2004). It first appears that fewer items had an NA higher than or equal to $80 \%$ for photographs (44\% in Bonin et al., 2004, and $65 \%$ for the present data). With only those items being used for comparisons (Table 6), naming latencies, VC, and AoA were the only variables showing important discrepancies between the two databases. These differences were significant for RT $[t(53)=-6.72, p<.001]$, NA $[t(56)=5.501, p<.001], \mathrm{VC}[t(56)=3.901, p<.001]$, and AoA $[t(56)=5.113, p<.001]$.

Using NA, IA, Fam, AoA, lexical frequency (F-Lex, log-transformed) and the number of phonemes as predictors of naming latencies in a multiple regression showed similar determinants at the .05 level in the two databases - NA, IA, and AoA. However, whereas IA appeared to be the most important determinant in the present data, it was AoA for Bonin et al.'s (2004) experiment. These principal determinants were the same in Bonin et al. (2004) when all items with NA higher than or equal to $50 \%$ were used.

For items common to the two databases, correlations between the same variables taken from the two databases were all significant at the .01 level, except for NA and VC (Table 7).

\section{DISCUSSION}

The goal of the present study was, first, to develop standardized French line action drawing materials and

Table 5

Simultaneous Multiple Regression Analyses on Reaction Time

\begin{tabular}{lrrc}
\hline Variable & $\beta$ & \multicolumn{1}{c}{$t$} & $p$ \\
\hline NA & -.288 & -3.742 & .0003 \\
IA & -.496 & -5.497 & .0001 \\
Fam & -.024 & -.250 & .8034 \\
IV & -.057 & -.500 & .6182 \\
AoA & .222 & 2.096 & .0386 \\
F-Lex & -.126 & -1.206 & .2305 \\
NbSyll & .141 & 1.801 & .0748 \\
\hline
\end{tabular}

Note-NA, name agreement; IA, image agreement; Fam, familiarity; IV, image variability; AoA, age of acquisition; F-Lex, lexical frequency; NbSyll, number of syllables. relate them to six psycholinguistic variables. Norms for NA on 172 line drawings were first collected, and action pictures with an NA inferior to $80 \%$ were excluded. IA, AoA, IV, VC, and Fam judgments were then obtained on 112 action pictures and the corresponding modal verbs.

Subjective judgments were used for collecting norms on IA, Fam, VC, IV, and AoA.

Pairwise correlations among variables showed negative correlations between AoA and two other variables, Fam and IV. Overall, the findings suggest that verbs are more familiar and provide a greater number of different mental images when they are learned early in life. The correlations between IV, Fam, and F-Lex were positive, suggesting that more frequent verbs are more conceptually familiar and generate a greater number of different mental images than do less frequent verbs (or the reverse).

Comparison with other normative data obtained from English and Spanish on the same line drawing materials underline that the obtained results have global similar tendencies for the variables Fam, VC, AoA, and F-Lex. Thus, interlanguage similar rating scores were observed for language-independent variables or visual-semantic variables, with the exception of IV. Moreover, interlanguage correlations were also observed for lexical variables, showing that similar patterns can appear between various languages, even for variables, such as F-Lex and AoA, that a priori seem specific to each language. On the other hand, no significant interlanguage correlations were observed for language-specific phonological variables (number of syllables and number of phonemes). These interlanguage correlations also corroborate the reliability of subjective rating scores. Indeed, studies comparing subjective and objective AoA data have already shown that correlations exist between these subjective measures and objective statements (Chalard, Bonin, Méot, Boyer, \& Fayol, 2003); the observation of interlanguage correlation further suggests the appropriateness of subjective ratings.

A comparison with French normative data obtained on photographs (Bonin et al., 2004) showed that fewer items obtained an NA higher than or equal to $80 \%$ for photographs than for line drawings. This indicates the relevance of using black-and-white line drawings in psycholinguistic research and in clinical practice, notwithstanding the fact that VC is considered more important for line drawings than for photographs.

The second goal of the study was to identify the reliable determinants of action-naming latencies. Naming latencies were collected on the 112 action line drawings. 
Table 6

Means and Standard Deviations for Different Sets of Items in the Bonin, Boyer, Méot, Fayol, and Droit (2004) Database and in the Present One

\begin{tabular}{|c|c|c|c|c|c|c|c|c|}
\hline & \multicolumn{4}{|c|}{ All Items With NA $>.8$} & \multicolumn{4}{|c|}{ Common Items Only } \\
\hline & \multicolumn{2}{|c|}{ Bonin et al. } & \multicolumn{2}{|c|}{ Schwitter et al. } & \multicolumn{2}{|c|}{ Bonin et al. } & \multicolumn{2}{|c|}{ Schwitter et al. } \\
\hline & $M$ & $S D$ & $M$ & $S D$ & $M$ & $S D$ & $M$ & $S D$ \\
\hline RT & 1,259 & 252 & 1,097 & 195 & 1,300 & 288 & 1,052 & 179 \\
\hline NA & 92.80 & 6.40 & 95.00 & 6.00 & 83.16 & 17.02 & 95.28 & 5.63 \\
\hline IA & 3.88 & 0.72 & 3.75 & 0.65 & 3.68 & 0.86 & 3.72 & 0.68 \\
\hline Fam & 3.08 & 1.04 & 2.99 & 0.90 & 2.91 & 1.07 & 2.98 & 0.90 \\
\hline $\mathrm{VC}$ & 2.23 & 0.76 & 2.91 & 0.68 & 2.37 & 0.82 & 2.82 & 0.65 \\
\hline AoA & 2.21 & 0.66 & 2.35 & 0.63 & 2.13 & 0.60 & 2.27 & 0.63 \\
\hline F-Lex & 25.72 & 37.25 & 20.70 & 28.02 & & & & \\
\hline NbPho & 4.97 & 1.09 & 4.96 & 1.07 & & & & \\
\hline
\end{tabular}

Note - RT, reaction time (naming latencies); NA, name agreement; IA, image agreement; Fam, familiarity; VC, visual complexity; AoA, age of acquisition; F-Lex, lexical frequency; NbPho, number of phonemes.

Naming latencies for the added pictures (VS) were slower than those for the MD pictures. These differences may be due to later AoA and lower Fam in the VS pictures. Besides, F-Lex is lower for the latter (word frequency per million: 25 vs. 15). Moreover, on common items, naming speeds are slower for action photographs (Bonin et al., 2004) than for line drawings.

NA, IA, and AoA contributed significantly to naming times. These results are consistent with other published studies on action-naming times. In the Spanish study of Cuetos and Alija (2003), AoA and NA were the best predictors of action-naming times. In this study, number of syllables and imageability also had a reliable influence on naming times, but with lower $\beta$ scores. As far as French is concerned, Bonin et al.'s (2004) action-naming study with photographs also showed that NA, IA, and AoA made a reliable contribution to naming times. F-Lex did not affect naming times in the present study when the other variables were held constant, nor in any of the studies mentioned on the naming of action pictures. The absence of a frequency effect in studies in which AoA was also controlled has already been outlined in object picture naming (Bonin et al., 2003; Carroll \& White, 1973; Morrison, Chappell, \& Ellis, 1997; Morrison, Ellis, \& Quinlan, 1992, but see Alario et al., 2004; Barry, Morrison, \& Ellis, 1997). F-Lex did not affect naming times in the present study, nor in any of the studies on action naming mentioned. It thus seems that the variables affecting

Table 7

Correlations Between the Same Variables for the Items Common to the Two Databases

\begin{tabular}{cccc}
\hline Variable & $n$ & $r$ & $p$ \\
\hline RT & 54 & .400 & .003 \\
NA & 57 & .233 & .081 \\
IA & 57 & .422 & .001 \\
Fam & 57 & .749 & .000 \\
VC & 57 & .318 & .016 \\
AoA & 57 & .942 & .000 \\
\hline
\end{tabular}

Note-RT, reaction time; NA, name agreement; IA, image agreement; Fam, familiarity; VC, visual complexity; AoA, age of acquisition; $n$, number of items. noun production elicited by the naming of line drawing pictures also affect verb naming. Indeed, only three variables systematically affected noun naming in all the normative studies conducted in several languages - that is, NA, IA, and AoA (for a review, see Alario et al., 2004). However, it is possible that such other variables as transitivity or argument structure, taken into consideration in neurolinguistic studies (Collina, Marangolo, \& Tabossi, 2001; Kim \& Thompson, 2000; Schneider \& Thompson, 2003), may have an effect on verb production.

In conclusion, this study provides French normative data for 112 line action pictures (see Appendix C) composed of 71 drawings taken from Masterson and Druks (1998) and 41 additional drawings and their corresponding verbs. We hope that this material will be a useful base for psycholinguistic researchers, as well as for the assessment and development of material for clinical purposes.

\section{REFERENCES}

Alario, F.-X., \& Ferrand, L. (1999). A set of 400 pictures standardized for French: Norms for name agreement, image agreement, familiarity, visual complexity, image variability, and age of acquisition. Behavior Research Methods, Instruments, \& Computers, 31, 531-552.

Alario, F.-X., Ferrand, L., Laganaro, M., New, B., Frauenfelder, U. H., \& SeguI, J. (2004). Predictors of picture naming speed. Behavior Research Methods, Instruments, \& Computers, 36, 140-155.

Barry, C., Morrison, C. M., \& Ellis, A. W. (1997). Naming the Snodgrass and Vanderwart pictures: Effects of age of acquisition, frequency, and name agreement. Quarterly Journal of Experimental Psychology, 50A, 560-585.

Bastianse, R., Hugen, J., Kos, M., \& van Zonneveld, R. (2002). Lexical, morphological, and syntactic aspects of verb production in agrammatic aphasics. Brain \& Language, 80, 142-159.

Berndt, R. S., Mitchum, C. C., Haendiges, A. N., \& Sandson, J. (1997). Verb retrieval in aphasia: 1. Characterizing single word impairments. Brain \& Language, 56, 68-106.

Bonin, P., Boyer, B., Méot, A., Fayol, M., \& Droit, S. (2004). Psycholinguistic norms for action photographs in French and their relationships with spoken and written latencies. Behavior Research Methods, Instruments, \& Computers, 36, 127-139.

Bonin, P., Peereman, R., Malardier, N., Méot, A., \& Chalard, M. (2003). A new set of 299 pictures for psycholinguistic studies: French norms for name agreement, image agreement, conceptual familiarity, visual complexity, image variability, age of acquisition, and naming latencies. Behavior Research Methods, Instruments, \& Computers, 35, 158-167. 
Caramazza, A., \& Hillis, A. E. (1991). Lexical organization of nouns and verbs in the brain. Nature, 349, 788-790.

Carroll, J. B., \& White, M. N. (1973). Age-of-acquisition norms for 220 picturable nouns. Journal of Verbal Learning \& Verbal Behavior, 12, 563-576.

Chalard, M., Bonin, P., Méot, A., Boyer, B., \& Fayol, M. (2003). Objective age-of-acquisition norms for a set of 230 object names in French: Relationship with psycholinguistic variables, the English data from Morrison et al. (1997), and naming latencies. European Journal of Cognitive Psychology, 15, 209-245.

Collina, S., Marangolo, P., \& Tabossi, P. (2001). The role of argument structure in the production of nouns and verbs. Neuropsychologia, 39, 1125-1137.

Cuetos, F., \& Alija, M. (2003). Normative data and naming times for action pictures. Behavior Research Methods, Instruments, \& Computers, 35, 168-177.

Cuetos, F., Ellis, A. W., \& Alvarez, B. (1999). Naming times for the Snodgrass and Vanderwart pictures in Spanish. Behavior Research Methods, Instruments, \& Computers, 31, 650-658.

Damasio, A. R., \& Tranel, D. (1993). Nouns and verbs are retrieved with differently distributed neural systems. Proceedings of the $\mathrm{Na}$ tional Academy of Sciences, 90, 4957-4960.

Dell'ACQua, R., LotTo, L., \& Job, R. (2000). Naming times and standardized norms for the Italian PD/DPSS set of 266 pictures: Direct comparisons with American, English, French, and Spanish published databases. Behavior Research Methods, Instruments, \& Computers, 32, 588-615.

DRUKS, J. (2002). Verbs and nouns: A review of the literature. Journal of Neurolinguistics, 15, 289-315.

FiEZ, J. A., \& Tranel, D. (1997). Standardized stimuli and procedures for investigating the retrieval of lexical and conceptual knowledge for actions. Memory \& Cognition, 25, 543-569.

Forster, K. I., \& Forster, J. C. (2003). DMDX: A Windows display program with millisecond accuracy. Behavior Research Methods, Instruments, \& Computers, 35, 116-124.

KIM, M., \& Thompson, C. K. (2000). Patterns of comprehension and production of nouns and verbs in agrammatism: Implications for lexical organization. Brain \& Language, 74, 1-25.

Masterson, J., \& DrUKs, J. (1998). Description of a set of 164 nouns and 102 verbs matched for printed word frequency, familiarity and age-of-acquisition. Journal of Neurolinguistics, 11, 331-354

McCARThy, R., \& WARrington, E. K. (1985). Category specificity in an agrammatic patient: The relative impairment of verb retrieval and comprehension. Neuropsychologia, 23, 709-727.

Molfese, D. L., Burger-Judisch, L. M., Gill, L. A., Golinkoff, R. M., \& HiRSCH-PASEK, K. A. (1996). Electrophysiological correlates of noun-verb processing in adults. Brain \& Language, 54, 388-413.

Morrison, C. M., Chappell, T. D., \& Ellis, A. W. (1997). Age of acquisition norms for a large set of object names and their relation to adult estimates and other variables. Quarterly Journal of Experimental Psychology, 50A, 528-559.

Morrison, C. M., Ellis, A. W., \& Quinlan, P. T. (1992). Age of acquisition, not word frequency, affects object naming, not object recognition. Memory \& Cognition, 20, 705-714.

New, B., Pallier, C., Ferrand, L., \& Matos, R. (2001). Une base de données lexicales du français contemporain sur Internet: LEXIQUE. L'Année Psychologique, 101, 447-462.

RAPP, B., \& CARAmazza, A. (1998). A case of selective difficulty in writing verbs. Neurocase, 4, 127-140.

Schneider, S. L., \& Thompson, C. K. (2003). Verb production in agrammatic aphasia: The influence of semantic class and argument structure properties on generalisation. Aphasiology, 17, 213-241.

SNODGRASS, J. G., \& VANDERWART, M. (1980). A standardized set of 260 pictures: Norms for name agreement, image agreement, familiarity and visual complexity. Journal of Experimental Psychology: Human Learning \& Memory, 6, 174-215.

\section{ARCHIVED MATERIALS}

The following materials and links may be accessed through the Psychonomic Society's Norms, Stimuli, and Data archive, http://www. psychonomic.org/archive/.

To access these files or links, search the archive for this article using the journal (Behavior Research Methods, Instruments, \& Computers), the first author's name (Schwitter), and the publication year (2004).

FILE: Schwitter-BRMIC-2004.zip.

DESCRIPTION: The compressed archive file contains three files:

schwitter2004norms.xls contains the norms developed by Schwitter et al. (2004), as Excel for Windows file. Each row represents 1 of the 112 words; each column one of the psycholinguistic variables.

schwitter2004norms.csv contains duplicate information in commadelimited format.

schwitter2004pictures.zip contains the 41 additional drawings.

AUTHOR's E-MAIL ADDRESS: valerie.schwitter@hcuge.ch. 
APPENDIX A

Modal and Other Responses for the MD Pictures

\begin{tabular}{|c|c|c|c|}
\hline Target Response & English & $\%$ & Other Responses \\
\hline aboyer & to bark & 100 & \\
\hline allumer & to light & 100 & \\
\hline arrêter & to stop & 61 & stopper $(34 \%)$, dire stop $(3 \%)$, circuler $(3 \%)$ \\
\hline arroser & to water & 100 & \\
\hline attraper & to catch & 39 & recevoir $(32 \%)$, rattraper $(21 \%)$, lancer $(5 \%)$, jouer $(3 \%)$ \\
\hline bâiller & to yawn & 97 & rire $(3 \%)$ \\
\hline bercer & to rock & 79 & $\begin{array}{l}\text { balancer }(11 \%) \text {, basculer }(3 \%) \text {, faire bouger }(3 \%) \text {, pousser }(3 \%) \text {, } \\
\text { secouer }(3 \%)\end{array}$ \\
\hline boire & to drink & 100 & \\
\hline caresser & to stroke & 92 & flatter $(3 \%)$, se reposer $(3 \%)$, s'ennuyer $(3 \%)$ \\
\hline chanter & to sing & 100 & \\
\hline chatouiller & to tickle & 100 & \\
\hline conduire & to drive & 97 & rouler $(3 \%)$ \\
\hline construire & to build & 76 & empiler (11\%), ajuster (3\%), bâtir (3\%), maçonner (3\%) \\
\hline coudre & to sew & 97 & raccommoder $(3 \%)$ \\
\hline couler & to sink & 97 & sombrer $(3 \%)$ \\
\hline couper & to cut & 61 & découper $(39 \%)$ \\
\hline courir & to run & 100 & \\
\hline creuser & to dig & 97 & peller $(3 \%)$ \\
\hline cuisiner & to cook & 100 & \\
\hline dactylographier & to type & 8 & taper à la machine $(84 \%)$ \\
\hline danser & to dance & 100 & \\
\hline défiler & to march & 16 & $\begin{array}{l}\text { marcher }(66 \%) \text {, marcher au pas }(5 \%) \text {, se battre }(3 \%) \text {, partir }(3 \%) \text {, } \\
\text { parader }(3 \%) \text {, marcher en rangs }(3 \%) \text {, guerroyer }(3 \%)\end{array}$ \\
\hline dessiner & to draw & 87 & peindre $(13 \%)$ \\
\hline dormir & to sleep & 100 & \\
\hline dribbler & to bounce & 71 & $\begin{array}{l}\text { jouer }(8 \%) \text {, rebondir }(5 \%) \text {, faire rebondir }(5 \%) \text {, faire du ballon } \\
(3 \%) \text {, jouer au ballon }(3 \%) \text {, jouer au basket }(3 \%) \text {, taper }(3 \%)\end{array}$ \\
\hline écrire & to write & 97 & rédiger $(3 \%)$ \\
\hline embrasser & to kiss & 89 & $\begin{array}{l}\text { baiser }(3 \%) \text {, donner bec }(3 \%) \text {, donner un baiser }(3 \%) \text {, faire un } \\
\text { bisou }(3 \%)\end{array}$ \\
\hline éternuer & to sneeze & 89 & atchoumer $(3 \%)$, expirer $(3 \%)$, respirer $(3 \%)$, se moucher $(3 \%)$ \\
\hline être assis & to sit & 37 & $\begin{array}{l}\text { s'asseoir }(47 \%) \text {, regarder }(5 \%) \text {, se reposer }(5 \%) \text {, attendre }(3 \%) \text {, } \\
\text { ne rien faire }(3 \%)\end{array}$ \\
\hline flotter & to float & 95 & dériver $(3 \%)$, vaguer $(3 \%)$ \\
\hline fondre & to melt & 87 & briller $(3 \%)$, chauffer $(3 \%)$, ensoleiller $(3 \%)$ \\
\hline frapper & to knock & 58 & toquer $(39 \%)$, taper $(3 \%)$ \\
\hline fumer & to smoke & 100 & \\
\hline glisser & to slide & 92 & descendre $(5 \%)$, faire du toboggan $(3 \%)$ \\
\hline goutter & to drip & 47 & couler $(42 \%)$, s'égoutter $(5 \%)$, fuir $(3 \%)$, tomber $(3 \%)$ \\
\hline grimper & to climb & 45 & $\begin{array}{l}\text { escalader }(24 \%) \text {, monter }(21 \%) \text {, descendre }(5 \%) \text {, équilibrer }(3 \%) \text {, } \\
\text { surpasser }(3 \%)\end{array}$ \\
\hline indiquer & to point & 3 & montrer $(53 \%)$, pointer $(45 \%)$ \\
\hline jongler & to juggle & 100 & \\
\hline jouer & to play & 100 & \\
\hline lacer & to tie & 63 & nouer $(18 \%)$, attacher $(13 \%)$, faire ses lacets $(3 \%)$ \\
\hline lâcher & to drop & 29 & $\begin{array}{l}\text { laisser tomber }(32 \%) \text {, tomber }(18 \%) \text {, faire tomber }(5 \%) \text {, } \\
\text { casser }(3 \%) \text {, choir }(3 \%) \text {, chuter }(3 \%) \text {, glisser }(3 \%) \text {, jouer }(3 \%) \text {, } \\
\text { renverser }(3 \%)\end{array}$ \\
\hline lécher & to lick & 100 & \\
\hline lire & to read & 100 & \\
\hline manger & to eat & 97 & sourire $(3 \%)$ \\
\hline marcher & to walk & 82 & se promener $(16 \%), \mathrm{NR}(3 \%)$ \\
\hline mendier & to beg & 84 & $\begin{array}{l}\text { quémander }(5 \%) \text {, demander }(3 \%) \text {, donner }(3 \%) \text {, } \\
\text { faire la manche }(3 \%) \text {, quêter }(3 \%)\end{array}$ \\
\hline monter cheval & to ride & 53 & $\begin{array}{l}\text { aller à cheval }(13 \%) \text {, chevaucher }(11 \%) \text {, faire du cheval }(11 \%) \text {, } \\
\text { galoper }(5 \%) \text {, faire du coco }(3 \%) \text {, se promener }(3 \%) \text {, trotter }(3 \%)\end{array}$ \\
\hline mordre & to bite & 100 & \\
\hline nager & to swim & 100 & \\
\hline naviguer & to sail & 55 & flotter $(24 \%)$, voguer $(13 \%)$, faire de la voile $(8 \%)$ \\
\hline neiger & to snow & 95 & tomber $(5 \%)$ \\
\hline
\end{tabular}


APPENDIX A (Continued)

\begin{tabular}{|c|c|c|c|}
\hline Target Response & English & $\%$ & Other Responses \\
\hline ouvrir & to open & 95 & appuyer (3\%), fermer (3\%) \\
\hline patiner & to skate & 92 & glisser $(8 \%)$ \\
\hline pêcher & to fish & 100 & \\
\hline peigner & to comb & 58 & se coiffer $(42 \%)$ \\
\hline peindre & to paint & 100 & \\
\hline peler & to peel & 45 & éplucher (53\%), plucher (3\%) \\
\hline percer & to drill & 87 & trouer $(5 \%)$, bricoler $(3 \%)$, forer $(3 \%)$, visser $(3 \%)$ \\
\hline pincer & to pinch & 100 & \\
\hline planter & to plant & 97 & enterrer $(3 \%)$ \\
\hline pleurer & to cry & 100 & \\
\hline pleuvoir & to rain & 100 & \\
\hline plier & to fold & 97 & NR $(3 \%)$ \\
\hline plonger & to dive & 97 & sauter $(3 \%)$ \\
\hline porter & to carry & 97 & marcher $(3 \%)$ \\
\hline poster & to post & 79 & envoyer $(21 \%)$ \\
\hline pousser & to push & 100 & \\
\hline prier & to pray & 100 & \\
\hline ramper & to crawl & 82 & $\begin{array}{l}\text { marcher à } 4 \text { pattes }(11 \%) \text {, avancer }(3 \%) \text {, marcher }(3 \%) \text {, } \\
\text { se déplacer }(3 \%)\end{array}$ \\
\hline ratisser & to rake & 34 & $\begin{array}{l}\text { ramasser }(45 \%) \text {, balayer }(11 \%) \text {, râteler }(5 \%) \text {, jardiner }(3 \%) \text {, } \\
\text { passer le râteau }(3 \%)\end{array}$ \\
\hline regarder & to watch & 100 & \\
\hline remuer & to stir & 37 & $\begin{array}{l}\text { mélanger }(21 \%) \text {, brasser }(13 \%) \text {, touiller }(13 \%) \text {, tourner }(11 \%) \text {, } \\
\text { cuisiner }(5 \%)\end{array}$ \\
\hline repasser & to iron & 100 & \\
\hline rêver & to dream & 100 & \\
\hline rire & to laugh & 92 & se marrer $(5 \%)$, s'esclaffer $(3 \%)$ \\
\hline rugir & to roar & 89 & crier $(5 \%)$, beugler $(3 \%)$, hurler $(3 \%)$ \\
\hline s'agenouiller & to kneel & 71 & $\begin{array}{l}\text { être à genoux }(8 \%) \text {, s'asseoir }(8 \%) \text {, être accroupi }(5 \%) \text {, prier } \\
(3 \%) \text {, rester }(3 \%), \text { NR }(3 \%)\end{array}$ \\
\hline saigner & to bleed & 100 & \\
\hline saluer & to wave & 71 & $\begin{array}{l}\text { faire un signe }(11 \%) \text {, dire au revoir }(5 \%) \text {, agiter la main }(3 \%) \text {, } \\
\text { partir }(3 \%) \text {, se quitter }(3 \%) \text {, secouer }(3 \%) \text {, NR }(3 \%)\end{array}$ \\
\hline s'appuyer & to lean & 82 & s'adosser $(13 \%)$, être appuyé $(3 \%)$, se reposer $(3 \%)$ \\
\hline sauter & to jump & 87 & descendre $(13 \%)$ \\
\hline sauter corde & to skip & 100 & \\
\hline se balancer & to swing & 97 & s'amuser (3\%) \\
\hline se laver & to wash & 100 & \\
\hline se pencher & to bend & 47 & se baisser $(37 \%)$, se plier $(8 \%)$, se courber $(5 \%)$, se cambrer $(3 \%)$ \\
\hline se peser & to weigh & 97 & regarder $(3 \%)$ \\
\hline se raser & to shave & 97 & gargouiller $(3 \%)$ \\
\hline shooter & to kick & 71 & lancer $(8 \%)$, taper $(8 \%)$, frapper $(5 \%)$, tirer $(5 \%)$, jouer $(3 \%)$ \\
\hline skier & to ski & 100 & \\
\hline sonner & to ring & 92 & faire sonner $(5 \%)$, tinter $(3 \%)$ \\
\hline souffler & to blow & 100 & \\
\hline sourire & to smile & 100 & \\
\hline tirer & to pull & 95 & promener $(3 \%)$, traîner $(3 \%)$ \\
\hline tirer coup feu & to shoot & 82 & chasser $(18 \%)$ \\
\hline tisser & to weave & 92 & coudre $(3 \%)$, filer $(5 \%)$ \\
\hline toucher & to touch & 76 & $\begin{array}{l}\text { NR }(11 \%) \text {, communiquer }(3 \%) \text {, contacter }(3 \%) \text {, frôler }(3 \%) \text {, } \\
\text { joindre }(3 \%) \text {, pointer }(3 \%)\end{array}$ \\
\hline traverser & to cross & 100 & \\
\hline tricoter & to knit & 95 & coudre $(5 \%)$ \\
\hline verser & to pour & 97 & renverser $(3 \%)$ \\
\hline voler & to fly & 100 & \\
\hline
\end{tabular}


APPENDIX B

Modal and Other Responses for the VS Pictures

\begin{tabular}{|c|c|c|c|}
\hline Target Response & English & $\%$ & Other Responses \\
\hline acheter & to buy & 63 & $\begin{array}{l}\text { payer }(21 \%) \text {, prendre }(5 \%) \text {, demander }(3 \%) \text {, donner }(3 \%) \text {, } \\
\text { recevoir }(3 \%) \text {, saisir }(3 \%)\end{array}$ \\
\hline applaudir & to applaud & 100 & \\
\hline attacher & to tie up & 100 & \\
\hline atterrir & to land & 95 & décoller $(3 \%)$, se poser $(3 \%)$ \\
\hline ausculter & to examine & 50 & écouter $(45 \%)$, mesurer $(3 \%)$, soigner $(3 \%)$ \\
\hline balayer & to sweep & 100 & \\
\hline bêcher & to dig & 47 & labourer $(16 \%)$, cultiver $(8 \%)$, jardiner $(8 \%)$, NR $(5 \%)$ \\
\hline bercer & to rock & 87 & balancer $(5 \%)$, porter $(5 \%)$, lander $(3 \%)$ \\
\hline briser & to break & 21 & casser $(68 \%)$, rompre $(5 \%)$, couper $(3 \%)$, fendre $(3 \%)$ \\
\hline bronzer & to $\tan$ & 100 & \\
\hline calculer & to calculate & 97 & numéroter $(3 \%)$ \\
\hline caresser & to stroke & 95 & flatter $(3 \%)$, porter $(3 \%)$ \\
\hline clouer & to nail & 63 & planter $(21 \%)$, enfoncer $(11 \%)$, taper $(5 \%)$ \\
\hline coiffer & to comb & 37 & peigner $(63 \%)$ \\
\hline coller & to stick & 29 & $\begin{array}{l}\text { timbrer }(45 \%) \text {, affranchir }(8 \%) \text {, poster }(5 \%) \text {, cacheter }(3 \%) \text {, } \\
\text { envoyer }(3 \%) \text {, estampiller }(3 \%) \text {, mettre }(3 \%) \text {, mettre un timbre } \\
(3 \%)\end{array}$ \\
\hline compter & to count & 84 & $\begin{array}{l}\text { payer }(5 \%) \text {, feuilleter }(3 \%) \text {, regarder }(3 \%) \text {, regarder des images } \\
(3 \%) \text {, NR }(3 \%)\end{array}$ \\
\hline coudre & to sew & 71 & recoudre $(16 \%)$, raccommoder $(8 \%)$, NR $(5 \%)$ \\
\hline crier & to shout & 84 & parler $(13 \%)$, hurler $(3 \%)$ \\
\hline cueillir & to pick & 84 & ramasser $(13 \%)$, attraper $(3 \%)$ \\
\hline débarrasser & to clear & 42 & $\begin{array}{l}\text { desservir }(16 \%) \text {, ramasser }(16 \%) \text {, prendre }(8 \%) \text {, enlever }(5 \%) \text {, } \\
\text { mettre la table }(5 \%) \text {, servir }(5 \%) \text {, déblayer }(3 \%)\end{array}$ \\
\hline déboucher & to uncork & 74 & débouchonner $(18 \%)$, ouvrir $(8 \%)$ \\
\hline décoller & to take off & 97 & voler $(3 \%)$ \\
\hline demander & to ask for & 21 & questionner $(47 \%)$, interroger $(24 \%)$, poser une question $(8 \%)$, \\
\hline dépasser & to pass & 84 & $\begin{array}{l}\text { devancer }(5 \%) \text {, conduire }(3 \%) \text {, doubler }(3 \%) \text {, précéder }(3 \%) \text {, } \\
\text { ralentir }(3 \%)\end{array}$ \\
\hline descendre & to go down & 100 & \\
\hline dessiner & to draw & 97 & $\operatorname{tracer}(3 \%)$ \\
\hline écouter & to listen & 89 & dormir $(5 \%)$, relaxer $(3 \%)$, s'assourdir $(3 \%)$ \\
\hline effacer & to clean & 87 & essuyer $(8 \%)$, nettoyer $(5 \%)$ \\
\hline entrer & to enter & 79 & rentrer $(13 \%)$, sortir $(5 \%)$, avancer $(3 \%)$ \\
\hline essuyer & to wipe & 89 & laver $(3 \%)$, lustrer $(3 \%)$, nettoyer $(3 \%)$, sécher $(3 \%)$ \\
\hline faucher & to mow & 53 & couper $(37 \%)$, arracher $(3 \%)$, scalper $(3 \%)$, tailler $(3 \%)$, NR $(3 \%)$ \\
\hline fermer & to close & 50 & ouvrir $(42 \%)$, aérer $(3 \%)$, entrouvrir $(3 \%)$, NR $(3 \%)$ \\
\hline filmer & to film & 95 & viser $(3 \%)$, visionner $(3 \%)$ \\
\hline gonfler & to pump up & 89 & pomper $(5 \%)$, jouer $(3 \%)$, regonfler $(3 \%)$ \\
\hline heurter & to hit & 11 & $\begin{array}{l}\text { se cogner }(68 \%) \text {, percuter }(11 \%) \text {, bousculer }(3 \%) \text {, frapper }(3 \%) \text {, } \\
\text { rentrer }(3 \%) \text {, se taper }(3 \%)\end{array}$ \\
\hline jeter & to throw & 100 & \\
\hline jouer & to play & 95 & chanter $(3 \%)$, faire de la musique $(3 \%)$ \\
\hline jurer & to swear & 82 & $\begin{array}{l}\text { bénir }(3 \%) \text {, faire serment }(3 \%) \text {, prêter serment }(3 \%) \text {, prier }(3 \%) \text {, } \\
\text { prononcer }(3 \%) \text {, recevoir }(3 \%) \text {, signer }(3 \%)\end{array}$ \\
\hline laver & to wash & 76 & essorer $(13 \%)$, lessiver $(5 \%)$, faire la lessive $(3 \%)$, remuer $(3 \%)$ \\
\hline mesurer & to measure & 95 & prendre une mesure $(3 \%)$, scier $(3 \%)$ \\
\hline nettoyer & to clean & 68 & laver $(26 \%)$, essuyer $(5 \%)$ \\
\hline offrir & to give & 92 & donner $(5 \%)$, recevoir $(3 \%)$ \\
\hline payer & to pay & 97 & donner $(3 \%)$ \\
\hline pédaler & to pedal & 58 & $\begin{array}{l}\text { aller à vélo }(11 \%) \text {, faire du vélo }(11 \%) \text {, rouler }(8 \%) \text {, aller }(3 \%) \text {, } \\
\text { aller en vélo }(3 \%) \text {, rouler à vélo }(3 \%), N R(5 \%)\end{array}$ \\
\hline
\end{tabular}


APPENDIX B (Continued)

\begin{tabular}{|c|c|c|c|}
\hline Target Response & English & $\%$ & Other Responses \\
\hline peindre & to paint & 100 & \\
\hline peser & to weigh & 95 & déposer $(3 \%)$, prendre $(3 \%)$ \\
\hline piquer & to prick & 100 & \\
\hline poignarder & to stab & 37 & $\begin{array}{l}\text { tuer }(45 \%) \text {, assassiner }(8 \%) \text {, agresser }(3 \%) \text {, enfoncer }(3 \%) \text {, mar- } \\
\text { quer }(3 \%) \text {, menacer }(3 \%)\end{array}$ \\
\hline presser & to squeeze & 97 & appuyer $(3 \%)$ \\
\hline punir & to punish & 87 & gronder $(8 \%)$, désigner $(3 \%)$, engueuler $(3 \%)$ \\
\hline ramer & to row & 87 & naviguer $(8 \%)$, faire du bateau $(5 \%)$ \\
\hline recevoir & to receive & 55 & $\begin{array}{l}\text { donner }(26 \%) \text {, prendre }(11 \%) \text {, distribuer }(3 \%) \text {, livrer courrier } \\
(3 \%) \text {, réceptionner }(3 \%)\end{array}$ \\
\hline recoller & to stick back & 71 & coller $(18 \%)$, réparer $(8 \%)$, bricoler $(3 \%)$ \\
\hline scier & to saw & 92 & couper $(8 \%)$ \\
\hline sculpter & to carve & 95 & marteler $(3 \%)$, taper $(3 \%)$ \\
\hline se casser & to break & 53 & $\begin{array}{l}\text { lâcher }(13 \%) \text {, laisser tomber }(11 \%) \text {, briser }(5 \%) \text {, lancer }(5 \%) \text {, } \\
\text { tomber }(5 \%) \text {, faire tomber }(3 \%) \text {, jeter }(3 \%) \text {, rompre }(3 \%)\end{array}$ \\
\hline se faner & to fade & 87 & flétrir $(8 \%)$, mourir $(5 \%)$ \\
\hline se noyer & to drown & 79 & couler $(21 \%)$ \\
\hline semer & to sow & 100 & \\
\hline s'enfuir & to run away & 32 & $\begin{array}{l}\text { fuir }(39 \%) \text {, courir }(18 \%) \text {, partir }(5 \%) \text {, s'échapper }(3 \%) \text {, } \\
\text { s'encourir }(3 \%)\end{array}$ \\
\hline siffler & to whistle & 100 & \\
\hline signer & to sign & 79 & écrire $(21 \%)$ \\
\hline sortir & to go out & 79 & $\begin{array}{l}\text { entrer }(11 \%) \text {, avancer }(3 \%) \text {, franchir }(3 \%) \text {, partir }(3 \%) \text {, rentrer } \\
(3 \%)\end{array}$ \\
\hline sucer & to suck & 97 & téter $(3 \%)$ \\
\hline suivre & to follow & 53 & $\begin{array}{l}\text { dépasser }(13 \%) \text {, rouler }(13 \%) \text {, poursuivre }(8 \%) \text {, conduire }(5 \%) \text {, } \\
\text { coller }(3 \%) \text {, doubler }(3 \%) \text {, faire de la moto }(3 \%)\end{array}$ \\
\hline suspendre & to hang & 21 & étendre $(66 \%)$, accrocher $(5 \%)$, pendre $(5 \%)$, sécher $(3 \%)$ \\
\hline tailler & to trim & 53 & $\begin{array}{l}\text { couper }(37 \%) \text {, ébourgeonner }(3 \%) \text {, élaguer }(3 \%) \text {, façonner }(3 \%) \text {, } \\
\text { sectionner }(3 \%)\end{array}$ \\
\hline téléphoner & to phone & 92 & appeler $(3 \%)$, composer $(5 \%)$ \\
\hline tirer & to pull & 97 & lutter $(3 \%)$ \\
\hline traire & to milk & 100 & \\
\hline viser & to aim at & 53 & tirer $(45 \%)$, pointer $(3 \%)$ \\
\hline visser & to screw on & 79 & tourner $(16 \%)$, dévisser $(5 \%)$ \\
\hline
\end{tabular}

Note-NR, no response. 


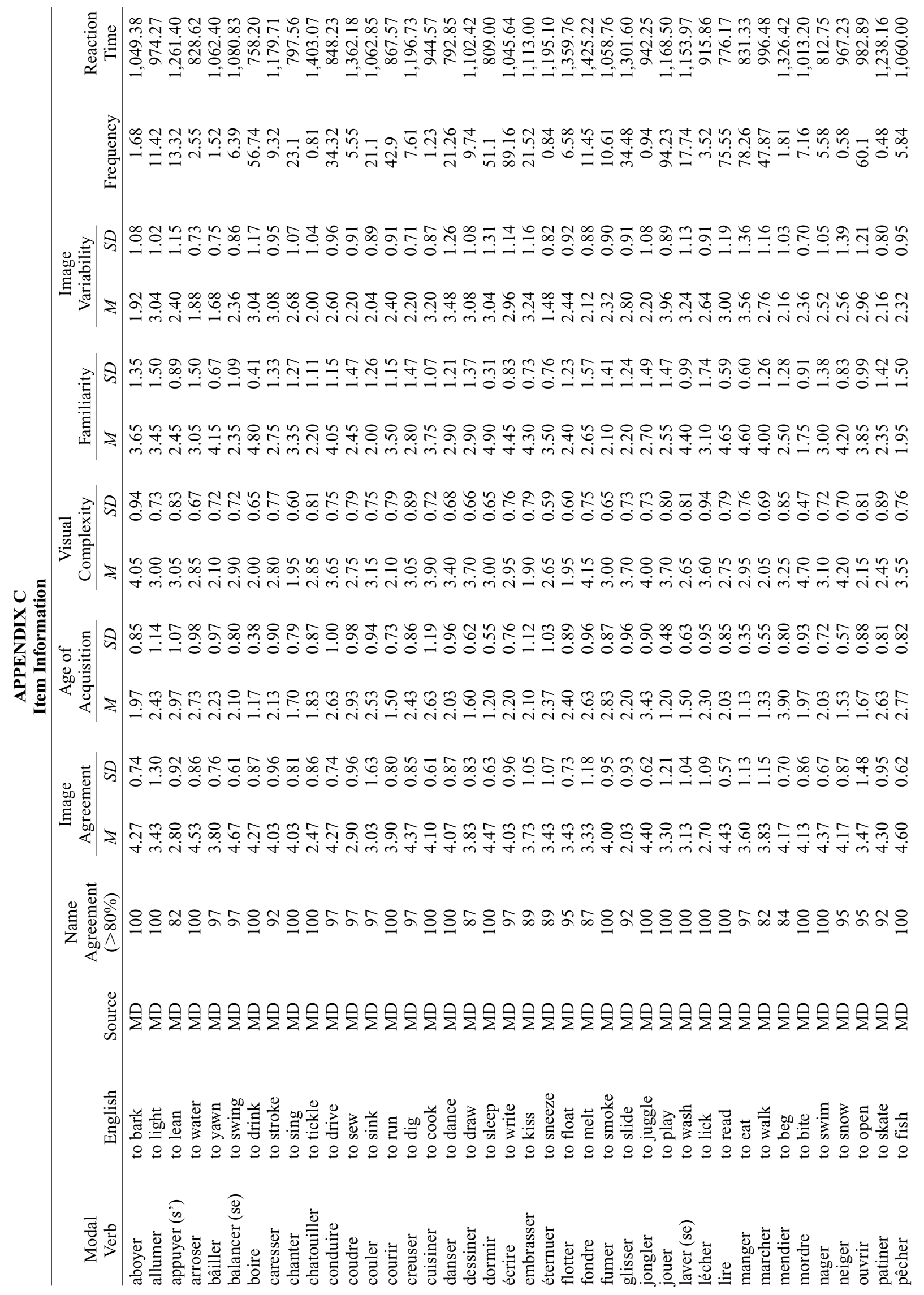




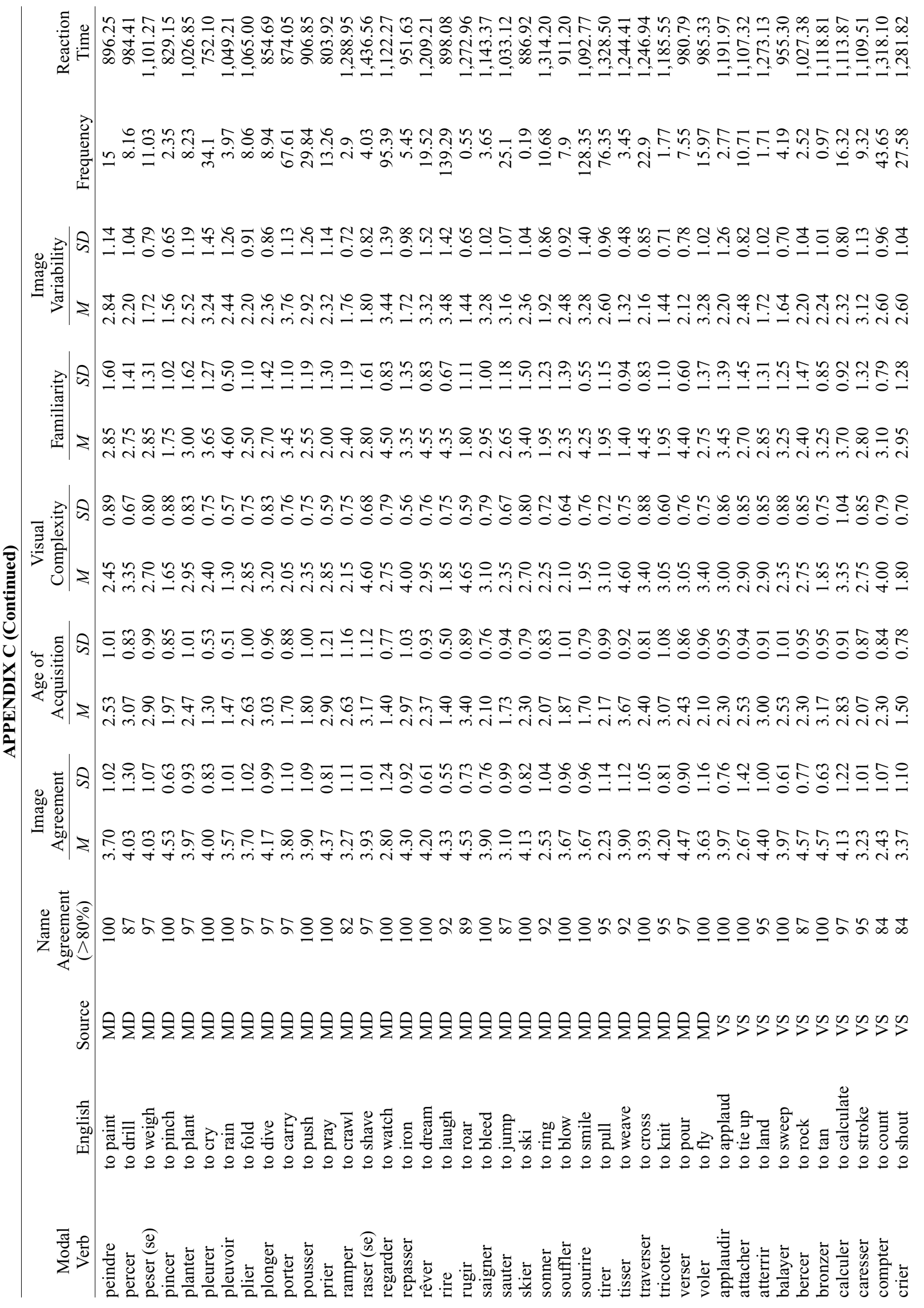




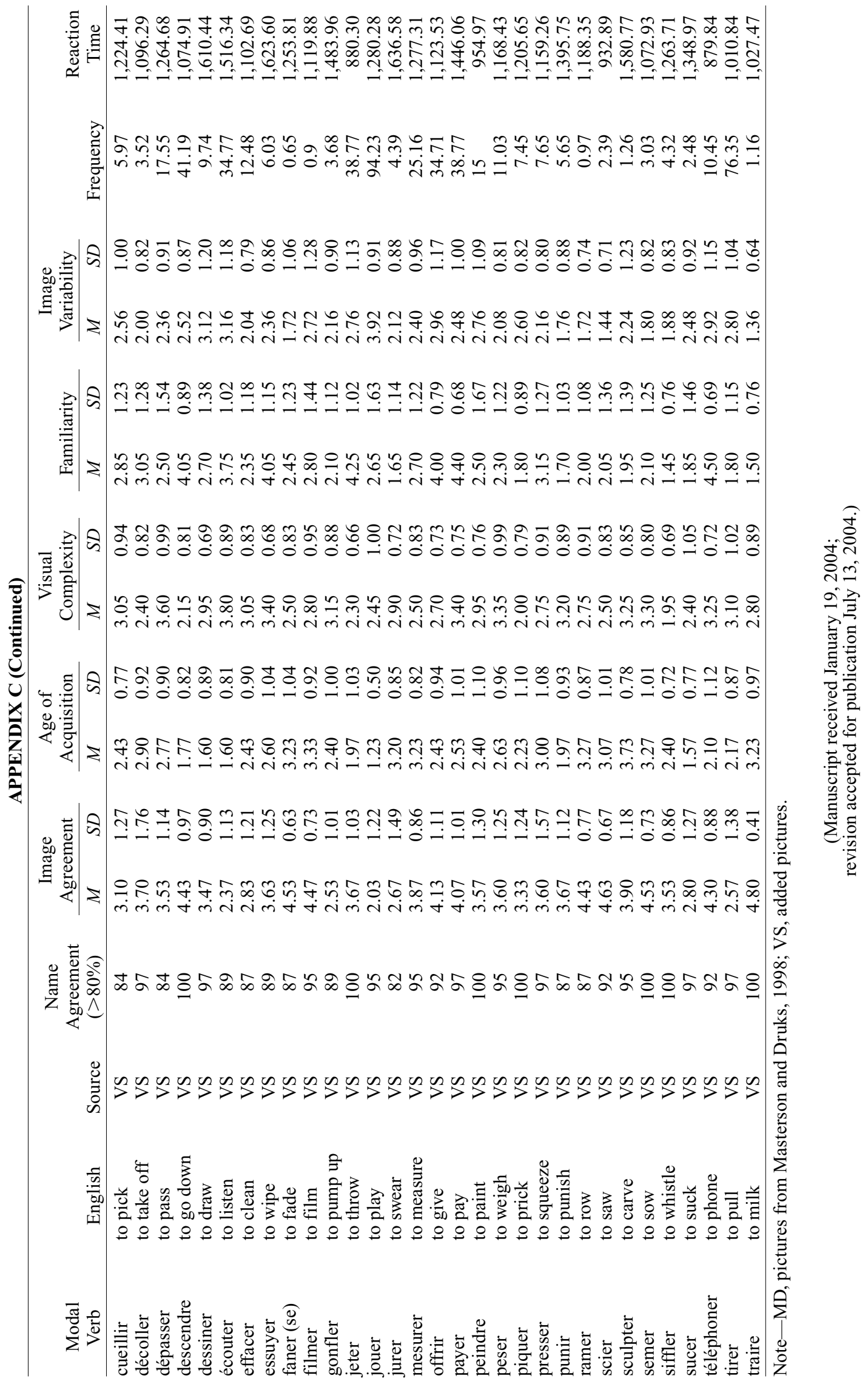

